\title{
Description of a new genus of Cryptochiridae (Decapoda: Brachyura) associated with Siderastrea (Anthozoa: Scleractinia), with notes on feeding habits
}

\author{
MARCELLE F.S. BADARO ${ }^{1}$, ELIZABETH G. NEVES ${ }^{1}$, PETER CASTRO ${ }^{2}$ and \\ RODRIGO JOHNSSON ${ }^{1}$ \\ ${ }^{1}$ Universidade Federal da Bahia, Instituto de Biologia, Departamento de Zoologia, LABIMAR (Crustacea, Cnidaria and \\ Fauna Associada), Adhemar de Barros, s/n, Campus de Ondina, Bahia, 40170-290 Brasil. \\ E-mail: r.johnsson@gmail.com \\ ${ }^{2}$ Biological Sciences Department, California State Polytechnic University, Pomona, 91768 CA, U.S.A.
}

\begin{abstract}
SUMMARY: Members of the Cryptochiridae are small gall-crabs that live as obligate symbionts of scleractinian corals. Only two species have so far been recorded in the western Atlantic Ocean. Herein a new Cryptochiridae genus and species is described, and new information is added on the life history of cryptochirids. The new genus is characterized by having the carapace with the lowest deflection angle among the genera, and also shows the following features: thoracic sternite 4 with setules and constriction smaller than half of the width of the basis, anterior margin curved with apical row of granules; third maxilliped with subcircular exopod reaching medially the lateral margin of the ischium; pereiopod 2 with prominent distomesial and anterolateral expansion on the merus, propodus almost twice larger than dactylus; thoracic sternite 7 with complete medial suture, female pleopod 3 uniramous with longitudinal opening. Male first pleopod straight with subdistal curvature of approximately $90^{\circ}$. Individuals belonging to the new genus are found in galls in massive corals although this structure is cited as being characteristic of ramified corals. The long plumose setae of the maxilliped 3 suggest a filter-feeding function, but the toothless chelae suggest that they are used to gather mucus.
\end{abstract}

Keywords: gall crab, associated fauna, coral reef, symbiosis, Cnidaria.

RESUMEN: Descripción de un nUeVo género de Cryptochiridae (Decapoda: Brachyura) asociado com Siderastrea (ANTHozoa: Scleractinia), con notas sobre los hábitos alimentarios. - Los miembros de la familia Cryptochiridae son pequeños cangrejos agallas que viven como simbiontes obligados en corales escleractiniarios. Sólo dos especies han sido registradas del Océano Atlántico occidental. Se describe un nuevo género y especie de Cryptochiridae asociados con corales de la familia Siderastreidae y se añade información sobre el ciclo de vida de los cryptochíridos. El nuevo género se caracteriza por tener el ángulo de desviación menor entre los géneros, que también muestra las siguientes características: esternón torácico 4 menor que la mitad del ancho del basis y el margen anterior curvo con una hilera de gránulos; tercero maxilípedo con exopodito subcircular, alcanzando el margen medial lateral del isquion; pereiópodo 2 con una prominente expansión distomesial e anterolateral en el mero, propodio casi dos veces más grande que el dáctilo; esternón torácico 7 con una sutura medial completa, pleópodo 3 unirrámeo, con abertura longitudinal. Pleópodo 1 del macho recto con curvature subdistal de alrededos $90^{\circ}$. Los individuos del nuevo género viven en agallas en corales masivos a pesar de que esta estructura es citada como características de corales ramificados. Las largas setas plumosas del maxilipedo 3 sugieren una función filtradora, pero las quelas sin dientes sugieren su uso para colectar moco.

Palabras clave: cangrejos agallas, fauna asociada, arrecifes de coral, simbiosis, Cnidaria. 


\section{INTRODUCTION}

The Cryptochiridae Paul'son 1875 constitutes a group of small, sexually dimorphic, cryptic crabs, commonly referred to as "gall-crabs" as they are all obligate symbionts of scleractinian corals.

Described from shallow tropical waters to depths of $140 \mathrm{~m}$ approximately, the family is so far represented by 20 genera and 46 species (Kropp and Manning 1995, Ng et al. 2008).

Sexual partners may inhabit distinct, adjoining cavities on the coral surface with contact occurring during breeding periods (Kropp and Manning 1987, Johnsson et al. 2006). Males usually may move from one colony to another to mate, and are occasionally found outside the cavities as free-living, benthic individuals (Potts 1915, Edmondson 1933, Fize and Serene 1957, Castro 1976, McCain and Coles 1979). Because of their small size, males have also been observed sharing a single gall with conspecific females, eventually attached to the females' abdomen (Henderson 1906, Warner 1977). In fact, it has been suggested that females are likely to be fertilized before the formation of the gall (Warner 1977). Once established on the host surface, cryptochirids are thought to affect or even inhibit coral growth through microscale environmental changes resulting in skeletal flattened spheres ("galls") or depressions ("pits") (Simon-Blecher et al. 1999). Nevertheless, while the galls have been mostly attributed to ramose colonies enclosing water-filtering crabs, the pits have been related to massive corals that usually shelter individuals adapted to feed on living and nonliving particles deposited on the border of the cavities (Potts 1915, Carricart-Ganivet et al. 2004). Hence, circumstantial differentiation among gall and "pit" dwellers has apparently provided a base for the correlation among the different feeding mechanisms of crabs, and the effectiveness of the morphological spatial arrays (branching vs. massive) of coral hosts (Abelson et al. 1993, Carricart-Ganivet et al. 2004).

Ecologically, there is no full agreement if the cryptochirid-scleractinian relationship may be interpreted as a case of commensalism, mutualism or parasitism (Kropp 1986, Abelson et al. 1991, Reed et al. 1992, SimonBlecher et al. 1999, Carricart-Ganivet et al. 2004).

Functionally, the symbiosis has been biased by a wide range of morphological and behavioral trends, such as the structure of mouthparts, chelae characteristics (Kropp 1986) and filter feeding (Potts 1915, Marshall and Orr 1960, Carricart-Ganivet et al. 2004) in contrast to feeding on coral mucus, tissues and/or trapped particulate material (Kropp 1986, Abelson et al. 1991, Simon-Blecher et al. 1999). Kropp (1986), however, pointed out discrepancies among the filterfeeding apparatus (such as the plumose net associated to the third maxillipeds, antennae and chelae) in other decapods, including caridean shrimps, porcellanid and anomuran crabs, and the fanning system of the cryptochirid maxillipeds, which supports the structure for collecting soft detrital material (as mucus) and tissue from the surface of the host.

Although remaining largely conjectural, as stated by Kropp (op. cit., p: 382) "ingestion of mucus by cryptochirids does not represent a metabolic drain on the host", and thus gall crabs are unlikely to fit into the category of parasites.

Data on Atlantic species are scattered and refer to the cryptochirids studied when Kropp and Manning (1987) revised the species recorded in the region and erected Detocarcinus (Kropp and Manning, 1987), Cecidocarcinus (Kropp and Manning, 1987) and Opecarcinus (Kropp and Manning, 1987), the former and the latter based on species from Troglocarcinus (Verril, 1908) and Pseudochryptochirus (Hiro, 1938) respectively. Since that revision, no new species records have been added to the Cryptochiridae inventory for the region and the gall crab fauna is exclusively restricted to the occurrence of four species Troglocarcinus corallicola (Verril, 1908), Detocarcinus balssi (Monod, 1956), Opercarcinus hypostegus (Shaw and Hopkins, 1977), and Cecidocarcinus brychius (Kropp and Manning, 1987), all belonging to monospecific genera. Apart from Johnsson et al. (2006), which extended the distribution of $O$. hipostegus and included some observations on the biology of the family, the literature on Brazilian chryptochirids is restricted to checklists (Coelho and Ramos-Porto 1995, Young 1998, Coelho et al. 2008) or ecological studies of coral associated fauna (Nogueira 2003, Oigman-Pszczol and Creed 2006).

The record of only two species of cryptochirids in Brazil seems more related to the reduced activity in taxonomic research than to the true faunal diversity, indicating that the diversity has been underestimated (Neves et al. 2006, Neves et al. 2008, Neves and Johnsson 2009).

Siderastrea is the most abundant scleractinian coral in Brazil, being easily found in shallow areas of the plateau reef flat, sometimes partially exposed to desiccation (Neves et al. 2006).

Detailed studies have indicated the existence of three siderastreids along the Brazilian coast (Neves et al. 2010) with $S$. radians and S. stellata being sympatric (Neves et al. 2008).

The present work describes a new genus and species of Cryptochiridae associated with siderastreids and adds new information to the life history of these organisms.

\section{MATERIALS AND METHODS}

Samples of Siderastrea showing crab galls were removed with a hammer and chisel from the reef plateau at depths up to $1.0 \mathrm{~m}$ in Guarajuba $\left(12^{\circ} 38^{\prime} \mathrm{S} / 38^{\circ} 03^{\prime} \mathrm{W}\right)$ and Praia do Forte beaches $\left(12^{\circ} 34^{\prime} \mathrm{S} / 37^{\circ} 59^{\prime} \mathrm{W}\right)$ in northern Bahia State (Brazil) (Fig. 1).

The colonies were immediately transferred to plastic bags and transported to the laboratory, where 

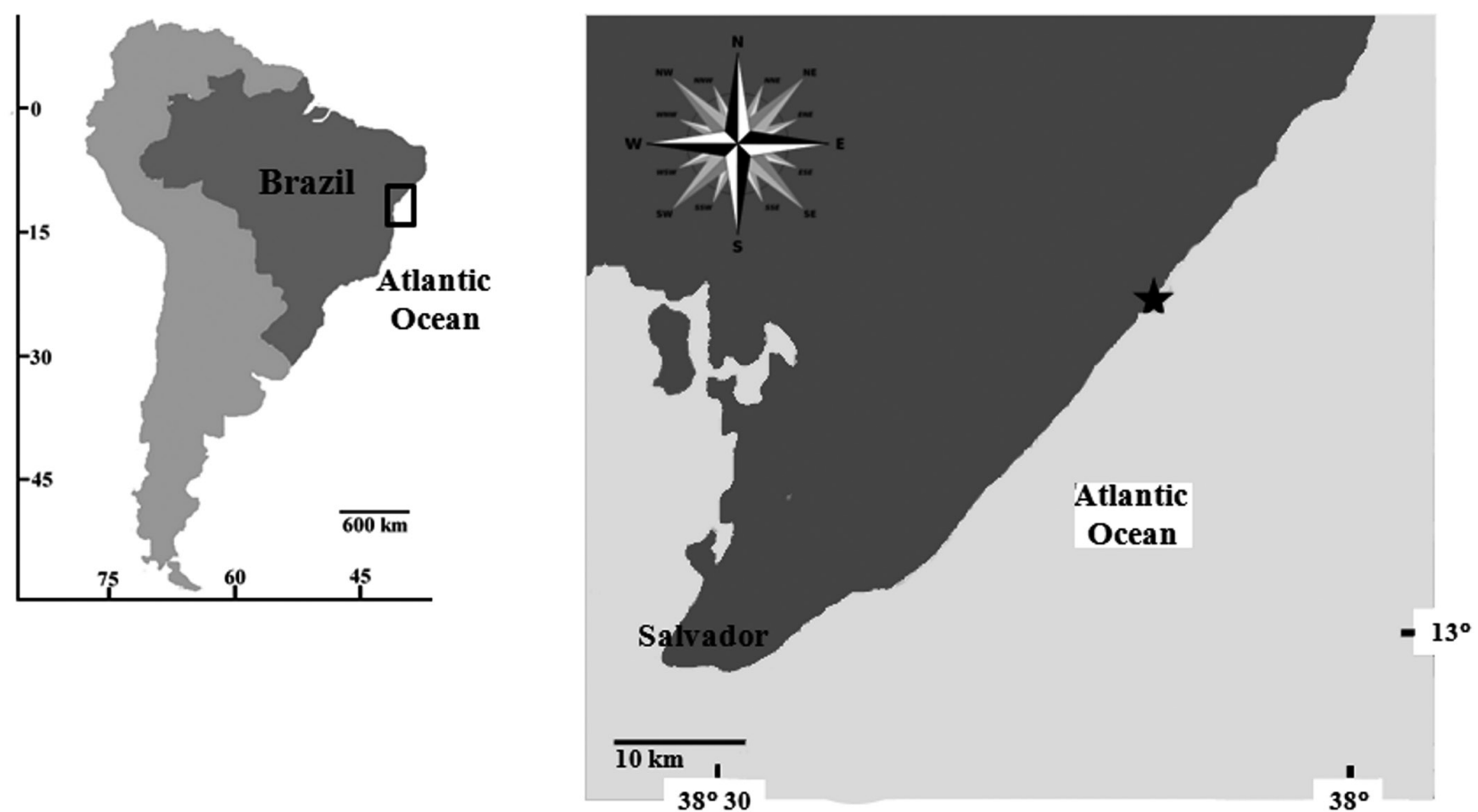

FIG. 1. - Type locality of Kroppcarcinus siderastreicola n. gen. n. sp. in Guarajuba Beach (black star) in Bahia State, northeastern Brazil.

crabs were located in the sediment or removed from galls under a stereomicroscope (NIKON SMZ 1000) with the aid of flexible forceps, and fixed in $90 \%$ alcohol.

Identification of the coral host was at genus level due to the impossibility of differentiating S. stellata and $S$. radians in the field. For the morphometric and taxonomic analyses, the specimens of Cryptochiridae were measured, dissected and photographed. Photographic documentation was obtained with a Nikon Coolpix 995 digital camera attached to the stereoscopic microscope. Appendages used in diagnosis and definition of the genera were mounted on permanent blades using CMC- $9 \circledR$ and then drawn using an Olympus CH30 optical microscope with a camera lucida. SEM images of the carapace were taken to elucidate the microstructure. Specimens were dried at room temperature for a period of $96 \mathrm{hrs}$, after which they were cleaned with a soft brush. The entire procedure for capturing the images was conducted at the Instituto de Quimica, Universidade Federal da Bahia (IQ/UFBA). The samples were mounted onto SEM stubs, and coated with $35 \mathrm{~nm}$ of gold in a Shimadzu IC-50 sputter coater. They were examined and photographed in a Shimadzu Superscan SS-550.

Terminology for the taxonomic description is based on Kropp (1990) and Kropp and Manning (1987). The following abbreviations are used: $\mathrm{m}$ (meters), mm (millimeters), cl (carapace length), cw (carapace width), MXP (maxilliped), ovig. (ovigerous), P (pereiopod), PLP (pleopod). Types were deposited in the Crustacea collection of the Museu de Zoologia da Universidade Federal da Bahia (UFBA).

\section{RESULTS}

Family CRYPTOChIRIDAe Paulson 1875

Cryptochiridae Paulson 1875

Lithoscaptidae Richters 1880

Hapalocarcinidae Calman 1900

\section{Kroppcarcinus n. gen.}

Diagnosis. Carapace longer than broad, deflected anteriorly on dorsal surface, widest posterior to midlength, pterygostomial region with suture separating it from carapace, anterolateral lobe absent.

Antennule apex with prominent spine. MXP3 with subcircular exopod reaching half length of outer margin of ischium; anteromesial lobe of ischium reaching merocarpal articulation; merus with prominent distolateral projection. Thoracic sternite 4 covered with setules with constriction smaller than half width of basis, anterior margin curved with apical row of distinct granules. Thoracic sternite 7 with complete medial suture. P2 merus with prominent distomesial and anterolateral expansions, carpus with moderate mesial expansion. PLP3 of female uniramous, longitudinal abdomen opening. Male PLP1 straight, curved approximately $90^{\circ}$ subdistally.

Type species. Kroppcarcinus siderastreicola $\mathrm{n} . \mathrm{sp}$., by present designation.

Etymology. Kroppcarcinus n. gen. is a combination of Kropp, in honor of Dr. Roy K. Kropp, who has dedicated a good part of his life to the study of Cryptochiridae, plus carcinus, Greek for "crab". 
Remarks. The Cryptochiridae is so far known by 20 described genera (Ng et al. 2008). Opecarcinus, Troglocarcinus, Cecidocarcinus and Detocarcinus are all recorded in the Atlantic Ocean - Opecarcinus in the western Atlantic and Ascension Island, Troglocarcinus has an amphiatlantic distribution, Cecidocarcinus occurs in deeper environments in the southeastern Atlantic (off western African coast) and in New Caledonia (Pacific Ocean), and Detocarcinus in the eastern Atlantic (western African coast) (Kropp and Manning 1987, Manning 1991).

The dorsal surface of the carapace of Kroppcarcinus n. gen. is deflected at an angle varying between $30^{\circ}$ and $35^{\circ}$, being $40^{\circ}$ in Opecarcinus (Kropp 1990), and approximately $60^{\circ}$ in Troglocarcinus (Kropp and Manning 1987). All remaining genera occurring in the Atlantic do not have detectable deflection in the carapace (Kropp and Manning 1987). The pterygostomial region of the new genus shows a suture separating it from the carapace as seen in Troglocarcinus and Cecidocarcinus, while in Opecarcinus and Detocarcinus the pterygostomian region is fused to the carapace.

Kroppcarcinus $\mathrm{n}$. gen. has a subcircular MXP3 exopod, reaching medially the lateral margin of the ischium as in Troglocarcinus, while in Opecarcinus and Cecidocarcinus it reaches $3 / 4$ of the total length of the ischium. Distinctly, Troglocarcinus and Cecidocarcinus have an oval exopod while in Opecarcinus it is elliptical. The exopod is absent in Detocarcinus. In Kroppcarcinus n. gen. the MXP3 has anteromesial lobe of the ischium extending to the merocarpal articulation, as observed in Cecidocarcinus. However, in all remaining Atlantic genera it extends beyond the referred articulation (Kropp and Manning 1987, Kropp 1990). The thoracic sternite 4 of Kroppcarcinus n. gen. is covered with setules, the constriction is smaller than half the width of the basis and the anterior margin is curved, with an apical row of granules, and is therefore structurally different from Troglocarcinus, which possesses a smooth sternite, the constriction is larger than half the width of the basis and the anterior margin it smooth, and Opecarcinus which shows a thoracic sternite 4 with a traverse line of tubercles close to the constriction and smaller tubercles near the insertion of the P1 (Kropp 1990: Fig.9c). In Detocarcinus the thoracic sternite 4 is granular, whereas in Cecidocarcinus the sternite is smooth (Kropp and Manning 1987: Figs. 1d and 3 b). Kroppcarcinus $\mathrm{n}$. gen. has $\mathrm{P} 2$ with prominent distomesial expansion on the merus as in Troglocarcinus and Cecidocarcinus, being discrete in Opecarcinus and Detocarcinus. The carpus of Troglocarcinus is highly prominent, being alternatively moderate in Kroppcarcinus n. gen. and Opecarcinus, and absent in Detocarcinus and Cecidocarcinus.

In Kroppcarcinus n. gen. the male PLP1 is straight with a subdistal curvature of approximately $90^{\circ}$, in Troglocarcinus PLP1 is slightly curved along his extension, while in Opecarcinus and Detocarcinus it is slightly curved distally with a robust tip directed later- ally at the apex. In Cecidocarcinus PLP1 is quite curved distally, with a robust tip at the apex and lobe expanded and directed laterally (Kropp and Manning 1987).

Besides these general characteristics, the P1 of Kroppcarcinus n. gen. is visible in the dorsal view in both sexes, while in Troglocarcinus and Opecarcinus the structure is visible just in the male.

In Detocarcinus the medial suture of sternite 7 is absent, but it is complete in Koppcarcinus n. gen. Other differentiating characteristics are the biramous PLP3 in the Detocarcinus and Cecidocarcinus females - in Kroppcarcinus n. gen., Opecarcinus and Troglocarcinus it is uniramous; and the female abdomen opening, transverse only in Detocarcinus (Kropp and Manning 1987) while in the rest of the genera, including Kroppcarcinus $\mathrm{n}$. gen., it is longitudinal.

Besides the two Atlantic genera, Troglocarcinus and Opecarcinus, eight other Cryptochiridae genera have an anteriorly deflected carapace as in Kroppcarcinus $\mathrm{n}$. gen. Among these genera, Neotroglocarcinus (Takeda and Tamura, 1980) and Zibrovia (Kropp and Manning, 1995 ) have sternite 4 with tubercles, therefore differing from the smooth sternite of the new genus.

In Cryptochirus (Heller, 1861), Dacryomaia (Kropp, 1990), Pelycomaia (Kropp, 1990), Lithoscaptus (A. Milne-Edwards, 1862) and Luciades (Kropp and Manning, 1995) the pterygostomial region is fused with the carapace, a trend not observed in Zibrovia, Fizesereneia (Takeda and Tamura, 1980), Neotroglocarcinus and Kroppcarcinus n. gen.

Kroppcarcinus $\mathrm{n}$. gen. is distinguishable from $\mathrm{Neo}$ troglocarcinus due to a medial suture of sternite 7 , but they share a distomesial expansion on the merus of P2 that is absent in all other genera.

Kroppcarcinus siderastreicola $\mathrm{n}$. sp. (Figs. 2-6)

Material examined. Female (holotype, UFBA 159) and male (allotype, UFBA 160), coll. in 23/XI/2006. 39 paratypes: being 4 males (UFBA 161) and 2 females (UFBA 170), coll. in 23/XI/2006; 3 males (UFBA 162), 1 female (UFBA 163) and 1 female dissected (UFBA 171), coll. in 26/I/2007; 6 males (UFBA 164), coll. in 19/ III/2007; 4 males (UFBA 165), coll. in 19/V/2007; 4 males (UFBA 166), 8 females (UFBA 174) and 2 females (used in electronic microscopy) (UFBA 175) coll. in 20/III/2008, all from Guarajuba, district of Camaçari (Bahia); 2 males (UFBA 172) and 2 females (UFBA 173), coll. in 12/I/2008 in Praia do Forte, district of Mata de São João (Bahia).

Description. Female: Carapace (Figs. 2A, 5A, 6A) 1.3 times longer than broad; slightly laterally inflated at branchial region, narrowing slightly towards front, as far as irregular depression near protogastric region; posterior surface convex. Anterolateral angle without lobe or spine; carapace with lateral margin lacking distinct border of tubercles.

Pterygostomial region completely separated from carapace by suture (Figs. 2B, C). Carapace concave anteriorly, with angle of deflection between $30^{\circ}$ and $35^{\circ}$ (Fig. 2B), surface covered by setae, granules and tubercles (Figs. 2A and 5A); numerous granules 


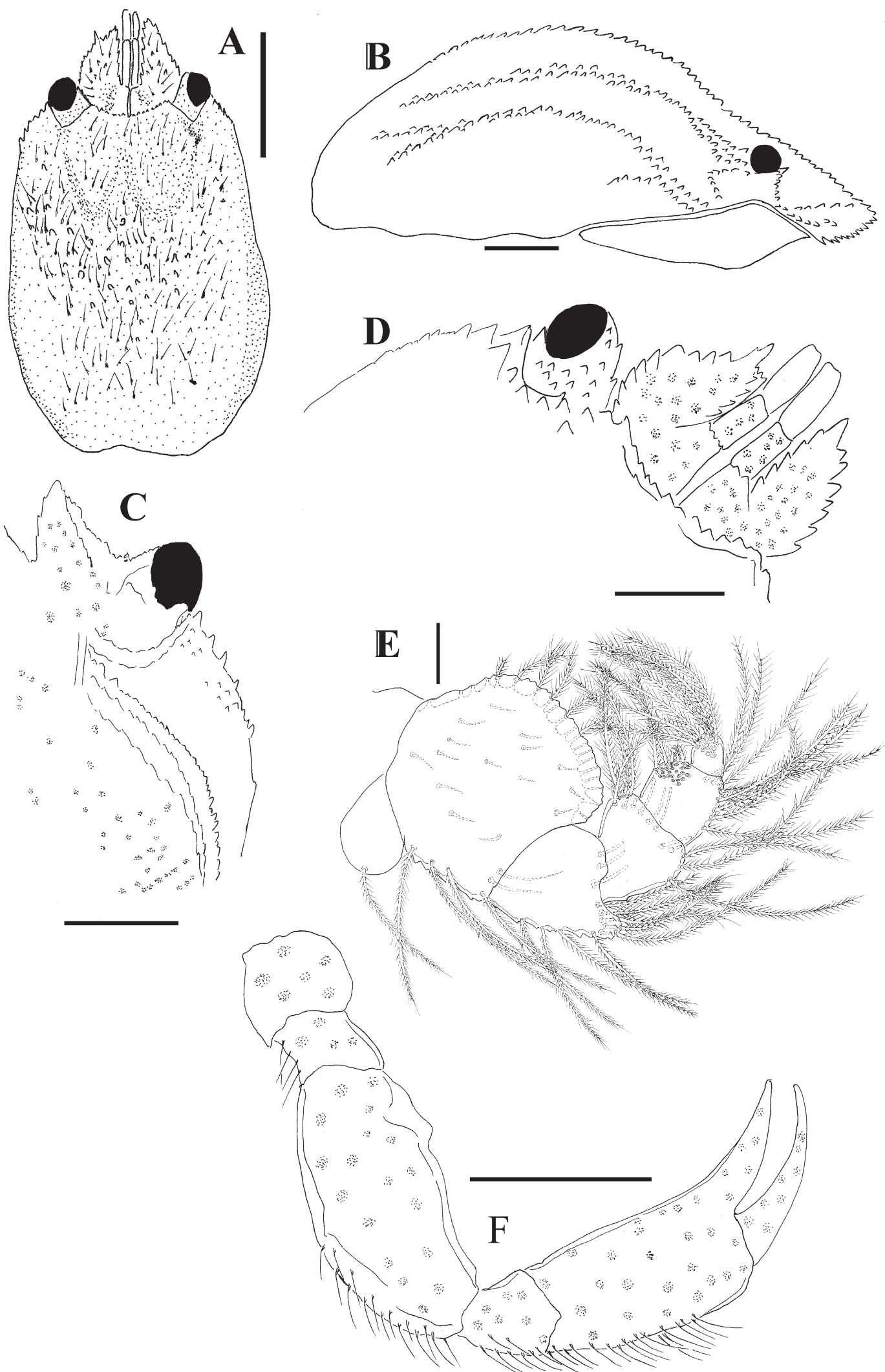

FIG. 2. - Kroppcarcinus siderastreicola n. gen. n. sp. Holotype female: A, carapace, dorsal view; B, carapace, lateral view; C, pterygostomial region with suture, ventral view; D, Anterolateral margin of carapace, dorsal view; E, third maxilliped; F, first cheliped. Scale bars: A, F, 1.0 $\mathrm{mm}$; B-E, $0.5 \mathrm{~mm}$. 


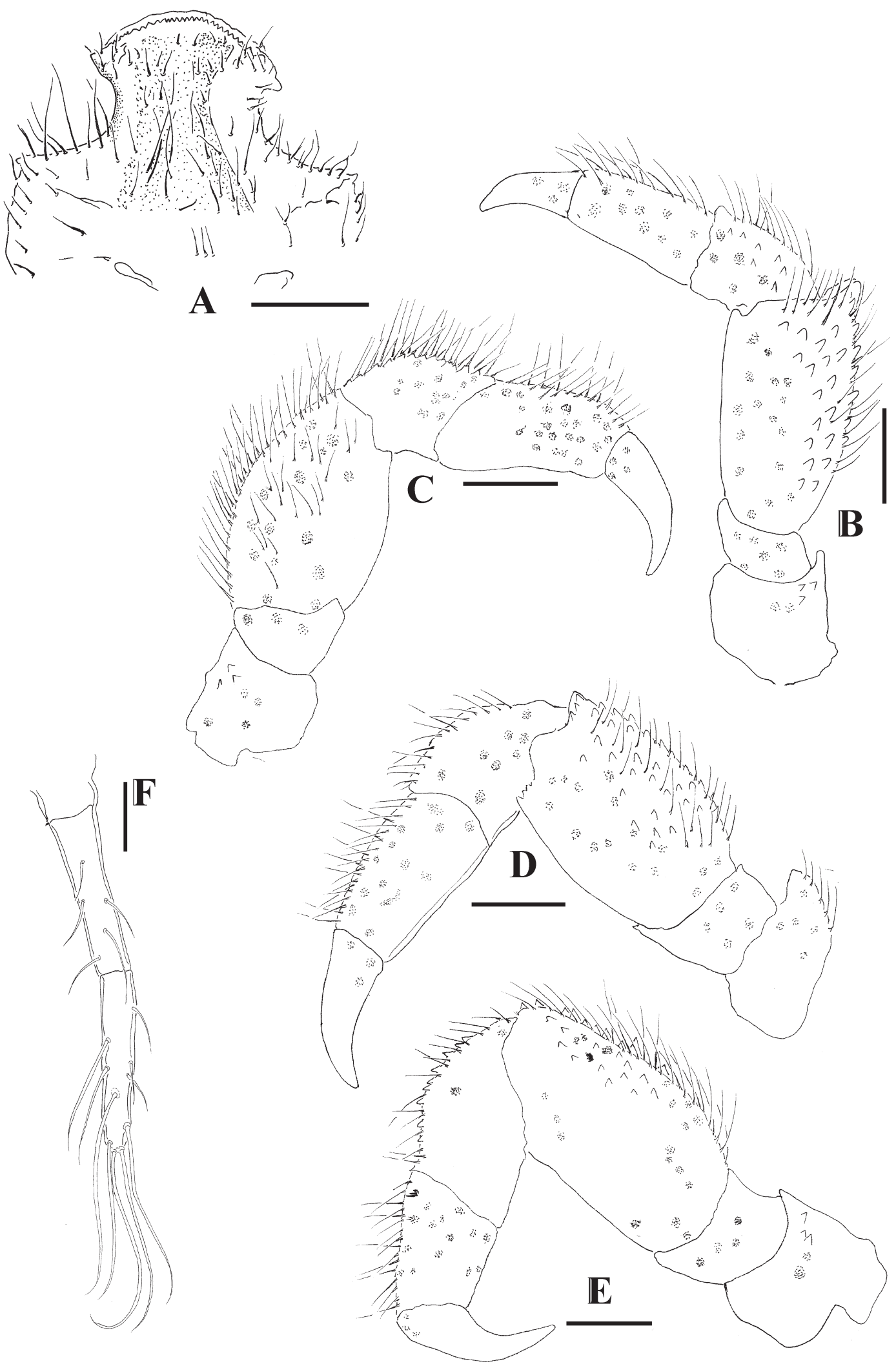

FIG. 3. - Kroppcarcinus siderastreicola n. gen. n. sp. Holotype female: A, sternite 4; B, pereiopod 2; C, pereiopod 3; D, pereiopod 4; E, pereiopod 5; F, pleopod 3. Scale bars: A-F, $0.5 \mathrm{~mm}$. 


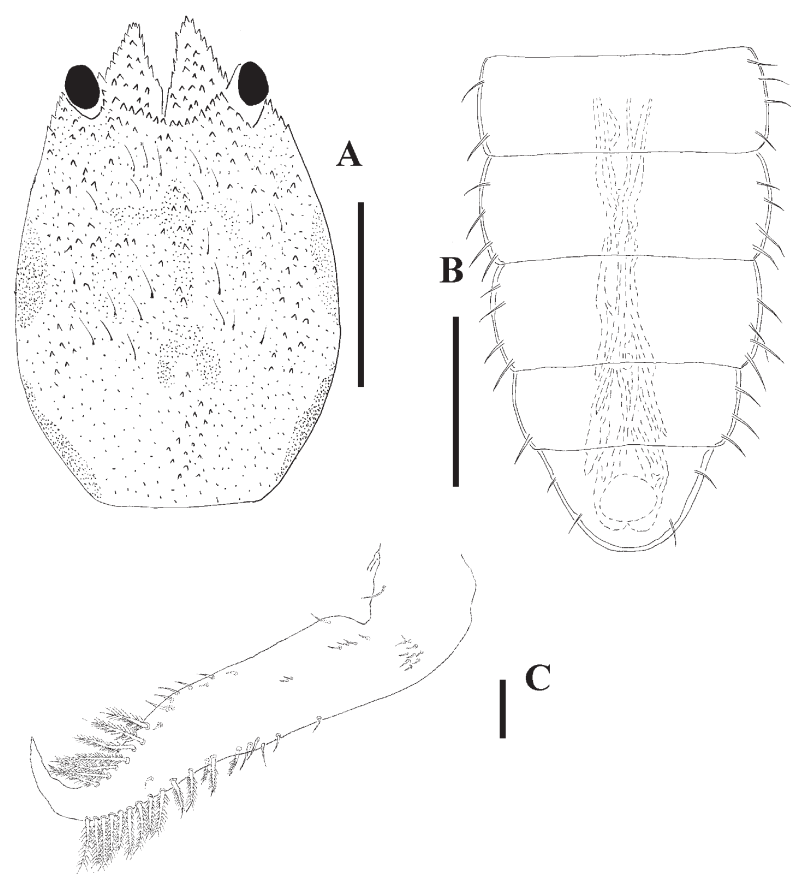

FIG. 4. - Kroppcarcinus siderastreicola $\mathrm{n}$. gen. n. sp. Allotype male: A, carapace, dorsal view; B, telson; C, pleopod 1. Scale bars: A, 1 $\mathrm{mm} ; \mathrm{B}-\mathrm{C}, 0.5 \mathrm{~mm}$
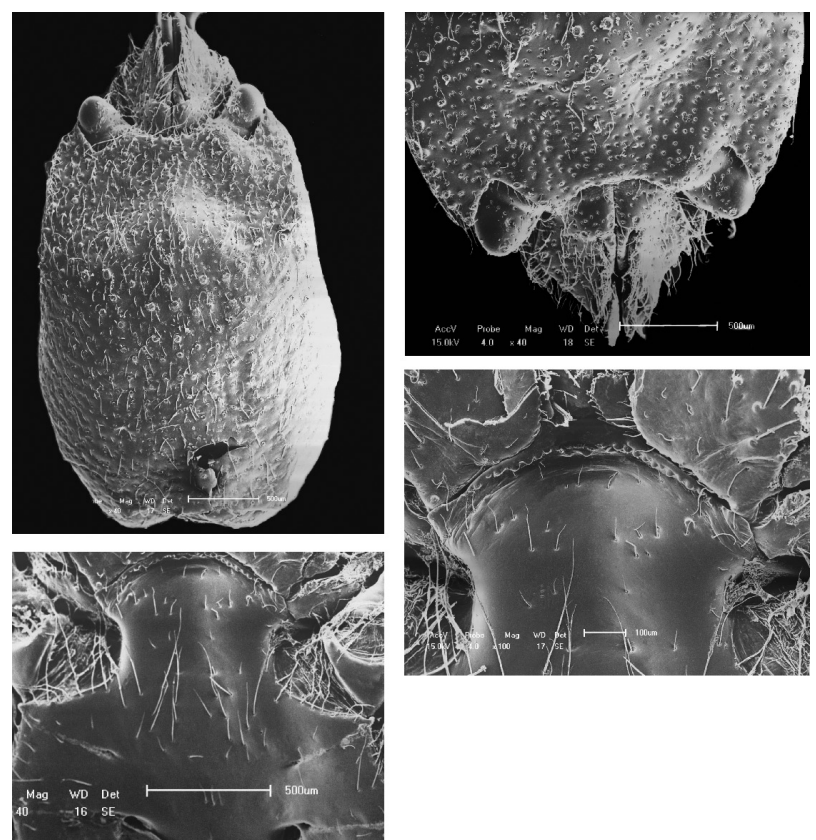

FIG. 5. - Kroppcarcinus siderastreicola n. gen. n. sp. Holotype female: A, carapace, dorsal view; B, anterior margin of carapace, dorsal view; $C$, sternite $4 ; \mathrm{D}$, anterior region of sternite 4 . Scale bars: A-B, D, $0.5 \mathrm{~mm} ; \mathrm{C}, 0.1 \mathrm{~mm}$.
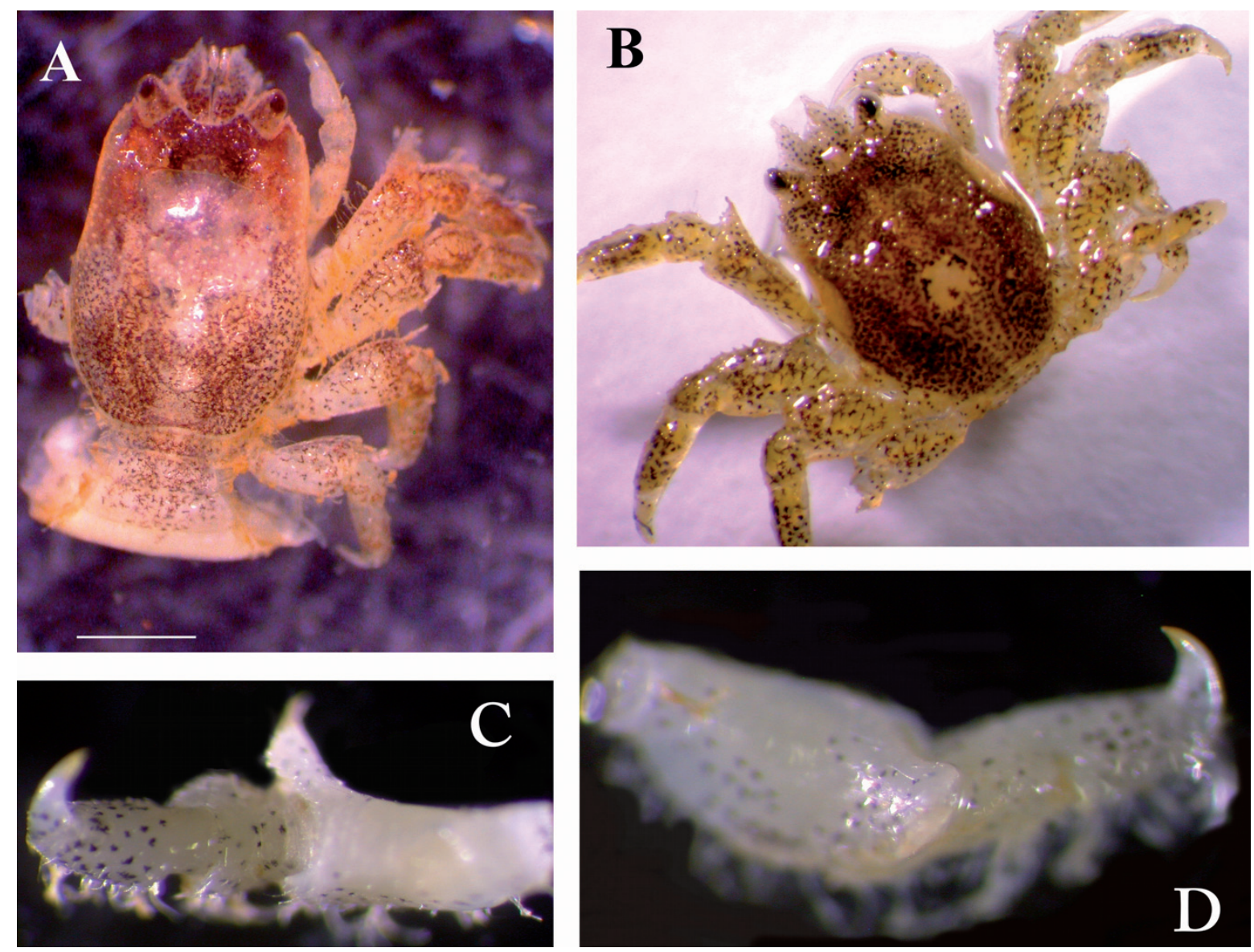

FIG. 6. - Kroppcarcinus siderastreicola n. gen. n. sp. A, holotype female, body, dorsal view; B, allotype male, body, dorsal view; C, anterolateral expansion of pleopod 2 merus; $\mathrm{D}$, anterolateral expansion of pleopod 2 merus, lateral view. 
posteriorly, sparse anteriorly; more frequent, robust tubercles along mid-line. Anterolateral margin with 5 spines (Fig. 2C). First spine located at outer orbital angle with apex crossing inner orbital angle. Orbit U-shaped, margin with few tubercles (Fig. 2D). Eyes directed anterolaterally, reaching anterolateral angle. Cornea anterolateral, hardly extending beyond anterolateral angle of carapace. Stalk covered by some setae, few tubercles, granules (Figs. 2D and 5B).

Antennule with lateral projection reaching inner margin of eyestalk; ornamented with spines, including prominent distal one, surface covered with setae and sparse small tubercles (Figs. 2D and 5B).

MXP3 (Fig. 2E) with subcircular exopod, reaching medially lateral margin of ischium, armed with seta; ischium covered with sparse setae, lateral margin toothed, with 4 setae, mesial margin with 6 setae and 14 insertions of possibly broken setae, anteromesial lobe of ischium reaching merocarpal articulation. Merus slightly longer than wide; narrower than half ischium width, external lateral margin toothed, with 6 insertions of setae; distolateral projection prominent, armed with 8 setae. Number of setae increasing considerably in the last three segments. All setae plumose. Remaining mouthparts as in representatives of Troglocarcinus and Opecarcinus.

Chelipeds (P1) (Fig. 2F) equal. Dactylus longer than dorsal margin of palm; smooth dorsally (Fig. 2F). Dorsal margin of palm showing small tubercles and setae. External surface of palm flat, with small setae. Carpus, merus tuberculate, dorsal margin with setae. Merus not extending beyond anterolateral angle of carapace, visible in dorsal view. Sternite 4 (Figs. 3A, 5C-D) with setae, constriction smaller than half of width of basis, anterior margin curved with distinct apical line of granules.

P2 to P4 (Figs. 3B-D) decreasing in size posteriorly, surface ornamented with setae, spines, granules and tubercles of varied sizes. Propodus of P2 almost twice larger than dactylus, P2 merus with prominent distomesial and anterolateral expansions, carpus with moderate mesial expansion (Figs. 3B, 6C-D). P3-P4 only slightly larger than dactylus. Coxa of P2 ornamented with spines and showing prominent distal projection (Fig. 3B). Merus with row of spines ranging from basi-ischium to distal projection (Fig. 3B). Mesial portion of carpus, propodus with tubercles, small spines (Fig3B). Coxa of P3 with distal projection (Fig. 3C); merus, carpus, propodus with mesial row of spines, setae (Fig. 3C), dactylus smooth, sharpened, quite curved distally.

P4 (Fig. 3D) with coxa slightly projected; tubercles, spines extending for the mesial portion of the merus. Merus showing medium distomesial (Fig. 3D) projection. P5 (Fig. 3E) with mesial portions of merus, carpus, propodus covered with tubercles, spines; long and curved dactylus. Female with PLP3 uniramous (Fig. $3 \mathrm{~F})$. Carapace of ovigerous female, slightly broader in dorsal view. Egg size (in alcohol) $0.4 \mathrm{~mm}$ maximum diameter.
Description. Male: similar to the female, though smaller (Figs. 4a, 6b). Cheliped more robust than in the female. Margins of abdomen convex, telson semi-oval (Fig. 4B). PLP-I with accentuated naked curvature distally (Fig. 4C). External lateral margin of PLP-I with a row of plumose setae ranging from the midlength to the end; inner lateral margin with plumose setae subdistally and proximal region covered with short setae.

Size range. female (ovigerous and non-ovigerous) $3.5 \times 2.7 \mathrm{~mm}$; to $2.1 \times 1.9 \mathrm{~mm}-$ based on 9 individuals; male $2.7 \times 2.2 \mathrm{~mm}$ to $2.0 \times 1.7 \mathrm{~mm}$ - based on 24 individuals.

\section{Coral host. Siderastrea sp.}

Distribution. Although Kroppcarcinus siderastreicola $\mathrm{n}$. gen. n. sp. has been recorded from the typelocality of Guarajuba and also in Praia do Forte, both located closely to the north coast of Bahia State, it is probable that it has a wider distribution, because the host is found from Rio de Janeiro to Maranhão States.

\section{DISCUSSION}

Cryptochirids are responsible for peculiar deformities in the growth pattern of coral colonies (SimonBlecher and Achituv 1997, Simon-Blecher et al. 1999). These organisms, however, do not follow the process of endolithic animals such as some bivalves, sponges and polychaetes, which perforate the calcium carbonate skeletal matrix, forming galleries and tunnels inside the corals (Tribollet and Golubic 2005). In fact, the cavities where the crabs are lodged derive solely from the contact of the symbiont' s body on the polyp, causing a local loss of tissue, followed by the feeding activities that can provoke small scale alterations in the circulation pattern of the water around the colony. Despite the cryptic habit of the females who live their life cycle inside the cavities, cryptochirids should be considered symbionts and part of the epibenthic fauna living associated with scleractinid corals.

As established by Carricart-Ganivet et al. (2004), the structure designated 'cavity' ('pits') is typically observed in massive corals, while those denominated 'galls' occur in branching corals. There is, however, no consensus about the use of these terms in the literature. In fact, it was not possible to apply this concept to $K$. siderastreicola $\mathrm{n}$. sp. and its coral host.

Siderastrea corals are distributed on the reef plateau along the northeast coast of Brazil, and include two species: the endemic $S$. stellata and the Caribean $S$. radians. Both are characterized by massive, eventually incrusting or slightly flat, semi- or spherical colonies (Neves 2004, Neves et al. 2006). Despite the host characteristics, the cavities of $K$. siderastreicola $n$. sp. (Fig. 6c) induce the formation of galls instead of pits as shown in the massive coral Mancina areolata by Carricart-Ganivet et al. (2004). 
The gall pattern of Kroppcarcinus n. gen. can be related to the colony morphology of Siderastrea, since a similar arrangement has been observed in incrusting colonies of Agaricia agaricites, another species hosting cryptochirids and found in shallow water. Galls therefore take on the shape of a dome corresponding to the exact outline of the crab lodged in its interior. It was also verified that the galls are shallow, being wider at the opening, and not extending beyond the length of the symbiont.

The feeding habit of cryptochirids may be related to the burrow type they occupy. Carricart-Ganivet et al. (2004) suggested that cavity inhabitants feed on the material deposited in the depression, while gall-formers feed on suspension material (e.g. filter-feeding).

Laboratory observations of live specimens of $K$. siderastreicola $\mathrm{n}$. sp., however, indicate that crabs do not follow any of these patterns.

The long and abundant plumose setae of the third maxilliped are similar to the homologous appendage described by Kropp (1986) for Utinomiella dimorpha, Favicolla rugosa and Hapalocarcinus marsupialis, suggesting a filter-feeding pattern as previously described among chriptochirids by Marshall and Orr (1960). Notwithstanding, the new species also uses the chelipeds to take food to the mouth parts as reported for H. marsupialis by Kropp (1986), which are capable of tearing tissue fragments with toothed chelae. The toothless chelae of the new species would hardly be able to undertake such a task and therefore are most probably used solely for gathering mucus portions for the mouth parts.

In spite of these characteristics, $K$. siderastreicola is not considered a parasite because the feeding habit based on filtering and mucus gathering agrees with Kropp's (1986) interpretation that such cryptochirids may not represent a metabolic drain.

Most studies on Brazilian cryptochirids have been restricted to ecological studies. Nogueira (2003) cited the occurrence of $T$. corallicola and $O$. hypostegus in colonies of Mussismilia hispida Verrill 1902. The identifications were possibly based on Melo (1996), in which there were only brief descriptions of the two species, cited as the only Brazilian representatives of the family. Melo (1996) did not list the species from the southeast coast of Brazil, and Opecracinus had not been described, until then, in association with representatives of mussid corals. Similarly, Oigman-Pszczol and Creed (2006) dealt with the distribution and abundance of the associated fauna Siderastrea stellata and Mussismilia hispida. No destructive methods were applied and they based their results solely on field observations. Considering the singular characteristics of the Brazilian coral fauna and the role played by the coral as a specialized habitat for several life forms, including the symbiotic gall crabs, which are important examples of co-adaptation and co-evolution in coral reef communities, it is expected that the updates and taxonomic revisions of fauna inventories will reveal a greater diversity than previously known for the South Atlantic.

\section{ACKNOWLEDGEMENTS}

We would like to thank N. Menezes and R. Canário (LABIMAR/UFBA), U. Lopes (LABPOR/UFBA) and G. Badaró Jr. for help during sampling procedures. M.L. Corrêa and Dra. S. Brandão, coordinators of the 'Grupo de Catalise e Polímeros' (IQ/UFBA) for the loan of the scanning microscope. C.C.P. de Souza (IQ/ UFBA) for technical support during the electronic microscopic procedure and image capturing. EGN and RJ thank Fundação de Amaparo a Pesquisa no Estado da Bahia (FAPESB) (APR469/2005) and Conselho Nacional de Pesquisa (CNPq) (470336/2004-8) respectively for financial support. The authors would also like to thank the two anonymous reviewers.

\section{REFERENCES}

Abelson A., Galil B.S., Loya Y. 1991. Skeletal modification in stony corals caused by indwelling crabs: hydrodynamical advantages for crab feeding. Symbiosis 10: 233-248.

Abelson A., Miloh T., Loya Y. 1993. Flow patterns induced by substrata and body morphologies of benthic organisms, and their roles in determining food particle availability. Limnol. Oceanogr. 38: 1116-1124.

Carricart-Ganivet J.P., Carrera-Parra L.F., Quan-Young L.I., Garia-Madrigal M.S. 2004. Ecological note on Troglocarcinus corallicola (Brachyura: Cryptochiridae) living in symbiosis with Manicina areolata (Cnidaria: Scleractina) in the Mexican Caribbean. Coral Reefs 23: 215-217.

Castro P. 1976. Brachyuran crabs symbiotic with scleractinian corals. Mar. Biol. 46: 237-245.

Coelho P.A., Ramos-Porto M. 1995. Distribuição ecológica dos crustáceos decápodas marinhos do nordeste do Brasil. Trab. Ocean. Univ. Fed. Pernambuco 23: 113-127.

Coelho P.A., Almeida A.O., Bezerra L.E.A. 2008. Checklist of the marine and estuarine Brachyura (Crustacea: Decapoda) of northern and northeastern Brazil. Zootaxa 1956: 1-58.

Edmondson C.H. 1933. Cryptochirus of the Central Pacific. Bull. Bishop Mus. 10: 3-23.

Fize A., Serene R. 1957. Les hapalocarcinides du Viet-Nam. Arch. Mus. Nat. Hist. Nat. Ser. 7 5: 1-202.

Henderson J.R. 1906. On a new species of coral-infesting crab taken by the R.I.M.S. Investigator' at the Andaman Islands. Ann. Mag. Nat. Hist. 18: 211-219.

Johnsson R., Neves E., Franco G.M.O., da Silveira F.L. 2006. The association of two gall crabs (Brachyura: Cryptochiridae) with the reef-building coral Siderastrea stellata Verrill, 1868. Hydrobiologia 559: 379-384.

Kropp R.K. 1986. Feeding biology and mouthpart morphology of three species of coral gall crabs (Decapoda: Cryptochiridae). J. Crustac. Biol. 6: 377-384.

Kropp R.K. 1990. Revision of the genera of gall crabs (Crustacea: Cryptochiridae) occurring in the Pacific Ocean. Pacific Sci. 44: 417-448.

Kropp R.K., Manning R.B. 1987. The Atlantic Gall Crabs, Family Cryptochiridae (Crustacea: Decapoda: Brachyura). Smithson. Contrib. Zool. 462: 1-21.

Kropp R.K., Manning R.B. 1995. Crustacea Decapoda: two new genera and species of deep water gall crabs from the Indo-west Pacific (Cryptochiridae). In: Crosnier, A. (ed.) Résultats des Campagnes MUSORSTOM, Volume 15. Mem. Mus. Nat. Hist. nat. 168: 531-539.

Manning R.B. 1991. Crustacea Decapoda: Cecidocarcinus zibrowii, a new deep-water gall crab (Cryptochiridae) from New Caledonia. In: Crosnier, A. (ed.) Résultats des Campagnes MUSORSTOM, Volume 9. Mem. Mus. Nat. Hist. nat. 152: 515-520.

Marshall S.M., Orr A.P. 1960. Feeding and nutrition. In: Waterman T.H. (ed.), The Physiology of Crustacea. Academic Press, New York, pp. 227-258.

McCain J.C., Coles S.L. 1979. A new species of crab (Brachyura, 
Hapalocarcinidae) inhabiting pocilloporid corals in Hawaii. Crustaceana 36: 8 1-89.

Melo G.A.S. 1996. Manual de Identificação dos Brachyura (Caranguejos e Siris) do Litoral Brasileiro. Éditora Pleiade, São Paulo, $455 \mathrm{pp}$.

Neves E.G. 2004. Complexo Siderastrea: espécies distintas? Significado da variabiliade do gênero Siderastrea de Blainville 1830 (Anthozoa, Scleractinia) no Brasil. Universidade de São Paulo, São Paulo, thesis, $458 \mathrm{pp}$.

Neves E.G., Johnsson R. 2009. Three new species of Artotrogidae (Copepoda, Siphonostomatoida) from the southeastern coast of Pernambuco State, Brazil. Zootaxa 1932: 47-60.

Neves E.G., Johnsson R., Sampaio C.L.S., Pichon M. 2006. The occurrence of Scolymia cubensis in Brazil: revising the problem of the Caribbean solitary mussids. Zootaxa 1366: 45-54.

Neves E.G., Andrade S.C.S., da Silveira F.L., Solferini V.N. 2008. Genetic variation and population structuring in two brooding coral species (Siderastrea stellata and Siderastrea radians) from Brazil. Genetica 132: 243-254.

Neves E.G., da Silveira F.L., Pichon M., Johnsson R. 2010. Cnidaria, Scleractinia, Siderastreidae, Siderastrea siderea (Ellis and Solander, 1786): Hartt Expedition and the first record of a Caribbean siderastreid in tropical Southwestern Atlantic. Check List 6: 505-510.

Ng P.K.L., Guinot D., Davie P.J.F. 2008. Systema Brachyurorum: Part I. An annotated checklist of extant brachyuran crabs of the world. Raffles Bull. Zool. 17: 1-286.

Nogueira J.M.M. 2003. Fauna living in colonies of Mussismilia hispida (Verrill) (Cnidaria: Scleractinia) in four South-eastern Brazil islands. Braz. Arch. Biol. Tech. 46: 421-432.
Oigman-Pszczol S.S. and Creed J.C. 2006. Distribution and abundance of fauna on living tissues of two Brazilian hermatypic corals (Mussismilia hispida (Verril 1902) and Siderastrea stellata (Verril, 1868). Hydrobiologia 563: 143-154.

Potts F.A. 1915. The fauna associated with crinoids of a tropical coral reef: with especial reference to its color variation. Pap. Carnegie Inst. 8: 73-96.

Reed J.K., Gore R.H., Scotto L.E., Wilson K.A. 1982. Community composition, structure, areal and trophic relationships of decapods associated with shallow- and deepwater Oculina varicosa reef corals. Bull. Mar. Sci. 32: 76 1-786.

Simon-Blecher N., Achituv Y. 1997. Relationship between the coral pit crab Cryptochirus corallioidytes Heller and its host coral. J. Exp. Mar. Biol. Ecol. 215: 93-102.

Simon-Blecher N., Chemedanov A., Eden N., Achituv Y. 1999. Pit structure and trophic relationship of the coral pit crab Cryptochirus coralliodytes. Mar. Biol. 134: 711-717.

Tribollet A., Golubic S. 2005. Cross-shelf differences in the pattern and pace of bioerosion of experimental carbonate substrates exposed for 3 years on the northern Great Barrier Reef, Australia. Coral Reefs 24: 422-434.

Young P.S. 1998. Catalogue of Crustacea of Brazil. Museu Nacional, Série Livros 6. Rio de Janeiro, 717 pp.

Warner G.F. 1977. The Biology of Crabs. Van Nostrand Reinhold Co, New York, 202 pp.

Scient. ed.: E. Macpherson.

Received November 9, 2011. Accepted March 12, 2012.

Published online August 2, 2012. 